\title{
Potentials for Reducing Cancer Incidence in Nigeria
}

\author{
Titilope M Dokunmu* \\ Biochemistry Department, Covenant University, Nigeria \\ *Corresponding author: Titilope M Dokunmu, Biochemistry Department, Covenant University, Nigeria
}

\section{ARTICLE INFO}

Received: 壎 January 23, 2019

Published: 崫 February 01, 2019
Citation: Titilope M Dokunmu. Potentials for Reducing Cancer Incidence in Nigeria. Biomed J Sci \& Tech Res 13(5)-2019. BJSTR. MS.ID.002474.

\section{Opinion}

Cancer genomics is changing oncology care and cancer detection rates in developed countries where genetic information can be used to improve care and management as well as inform decisions for personalized care for individuals owing to disparities in cancer genetics globally [1-3]. However, in some low and lower middle income countries, the battle against cancer is increasing [4]. For instance in Nigeria, cancer incidence and burden is growing with more than 115,000 new cases and over 70,000 deaths reported in 2018, with breast cancer as the leading type and cause of cancer mortality in the country [4,5]. Delays in detection, late presentation, poor access to treatment, poor prevention practice and knowledge and awareness all play significant roles in this increasing burdens while modifiable and unmodifiable risk factors for cancers have been identified [6-11]. Genetic predisposition account for some types of cancers originating from germ line mutations which increases the risk of developing especially ovarian, breast, colorectal, prostate and other cancers [12,13].

Although these hereditary cancers are inherited from parents, it does not always develop in their children. Because cancer cells undergo genetic changes which are detectable by high-throughput DNA sequencing, panel-based pathogenic gene screening through genetic testing, present many advantages for cancer management $[14,15]$, but it is not without its challenges. This technology is however yet to be explored for reducing cancer burdens or for cancer care management in Nigeria. Genetic contributions to cancer have been studied widely in many populations and there are peculiarities in different populations; in the African descent. For instance, hereditary breast and ovarian cancers have been linked mostly to BRCA1 and BRCA 2 mutations in African and non-African populations $[13,16]$, however, Africans are known to develop aggressive cancers and are at higher risks of deaths than other races. These variants of BRCA gene mutations in Nigerian population have been studied [19]. These unique genetic patterns and disparities should form the impetus for tailoring prevention, care and management for target populations with risk factors - like gender and ageing; which are not modifiable, and in turn greatly reducing the rising burden of cancers in Nigeria.

Breast and prostate cancers are two key cancer types that are prominent in Nigerians and the risk for both can be tested through genetic testing and potentially can overcome challenges of late presentation of patients which affects treatment outcomes and improve ways of managing and reducing cancer disease in Nigerian population. Mass screening for detection of new cases has helped previously in Nigeria and together with genetic testing and known modifiable risk factors linked to carcinomas in Nigerians $[10,11,17,18]$, can reduce the risk of developing the disease. The tests are becoming available for home use and can detect early individuals who are at higher risk of cancer or those with a family history $[19,20]$. With adjustment of lifestyle, this can greatly reduce their risk of developing cancers and improve care and management for those affected in Nigeria.

\section{References}

1. Schilsky RL (2014) Implementing personalized cancer care. Nature Reviews Clinical Oncology 11(7): 432-438.

2. Valencia OM, Samuel SE, Viscusi RK, Riall TS, Neumayer LA, Aziz H (2017) The role of genetic testing in patients with breast cancer: A review. JAMA Surg 152(6): 589-594.

3. Yip CH, Evans DG, Agarwal G, Buccimazza I, Kwong A, et al. (2019) Global Disparities in Breast Cancer Genetics Testing, Counselling and Management. World J Surg 4.

4. Globocan (2018) The Global Cancer Observatory.

5. Globocan (2012) The Global Cancer Observatory.

6. Azubuike S (2017) Breast cancer risk factors and signs: How much do Nigerian women know? Int. J Adv Med Health Res 4(1): 40. 
7. Okobia M, Bunker C, Zmuda J, Kammerer C, Vogel V, et al. (2006) Casecontrol study of risk factors for breast cancer in Nigerian women. Int J Cancer 119(9): 2179-2185.

8. Morounke SG, Ayorinde JB, Benedict AO, Adedayo FF, Adewale FO, et al. (2017) Epidemiology and Incidence of Common Cancers in Nigeria. Cancer Biol Res 5(3): 1105.

9. Agbo SP, Oboirien M (2016) Risk Factors for Breast Cancer in Sokoto, Nigeria. Merit Research Journal of Medicine and Medical Sciences 4(11) 465-471.

10. Adibe MO, Aluh DO, Isah A, Anosike C (2017) Knowledge, attitudes and perception of prostate cancer among male staff of the University of Nigeria. Asian Pac J Cancer Prev 18(7): 1961-1966.

11. Oluwole EO, Mohammed AS, Akinyinka MR, Salako O (2017) Cervical cancer awareness and screening uptake among rural women in Lagos, Nigeria. J Comm Med Primary Health Care 29(1): 81-88.

12. Knudson AG (2002) Cancer genetics. Am J Med Genet 111(1): 96-102.

13. Olopade OI, Fackenthal JD, Dunston G, Tainsky MA, Collins F, et al. (2003) Breast Cancer Genetics in African Americans. Supplement to Cancer 97(1): 236-245.

\section{ISSN: 2574-1241}

DOI: 10.26717.BJSTR.2019.13.002474

Titilope M Dokunmu. Biomed J Sci \& Tech Res

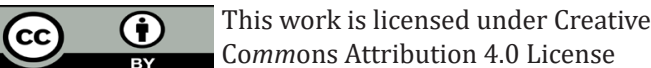

Submission Link: https://biomedres.us/submit-manuscript.php
14. Paterson R, Phillips KA (2017) Genetic testing in women with breast cancer: implications for treatment. Expert Rev Anticancer Ther 17(11): 991-1002.

15. Mc Cuaig JM, Tone AA, Maganti M, Romagnuolo T, Ricker N, et al. (2010) Modified panel-based genetic counseling for ovarian cancer susceptibility: A randomized non-inferiority study. Gynecol Oncol pii: S0090-8258(18): 31541-31545.

16. Feng Y, Rhie SK, Huo D, Ruiz Narvaez EA, Haddad SA, et al. (2017) Characterizing Genetic Susceptibility to Breast Cancer in Women of African Ancestry. Cancer Epidemiol Biomarkers Prev 26(7): 1016-1026.

17. Jedy Agba E, Curado MP, Ogunbiyi O, Oga E, Fabowale T, et al. (2012) Cancer incidence in Nigeria: a report from population-based cancer registries. Cancer Epidemiol 36(5): 2710-278.

18. Sule, ST, Sani M, Ukwenya EJ (2014) Risk factors for common cancers in Nigeria: Knowledge, attitudes and practice among secondary school students in Kaduna, Nigeria. Int J Med Med Sc 6: 34-41.

19. Zheng Y, Walsh T, Gulsuner S, Casadei S, Lee MK, et al. (2018) Inherited breast cancer in Nigerian women. J Clin Oncol 36(28): 2820-2825.

20. (2019) Breast Cancer Risk and Prevention.

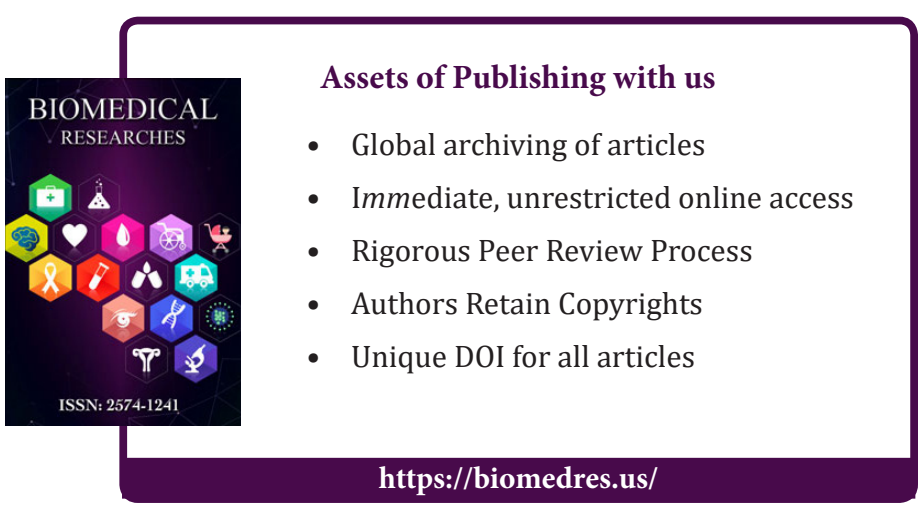

